\title{
RAFAŁ MICHLIŃSKI
}

ORCID 0000-0002-6389-2371

\section{Nowy adres Wroctaw 1946-1948. Korespondencja Ryszarda iZofii Gansińców, redakcja naukowa R. Gansiniec, K. Król- czyk, Warszawa 2020, s. 312}

DOI: $10.15290 /$ sp.2021.29.14

W 2020 r. na rynku wydawniczym ukazała się książka pt. Nowy adres Wrocław 1946-1948. Korespondencja Ryszarda i Zofii Gansinców pod redakcją naukową Radości Gansiniec oraz Krzysztofa Królczyka. Praca stanowi 19. tom serii wydawanej przez Uniwersytet Warszawski Akme Studia Historica pod redakcją prof. Ryszarda Kuleszy (Instytut Historii UW). Fakt wydania korespondencji uczonych jest o tyle istotny, iż książka stanowi pełną edycję wszystkich zachowanych do dziś listów Ryszarda i Zofii Gansińców oraz listy do nich przychodzące w latach 1946-1948. Za redakcję naukową pracy odpowiedzialni byli dr Radość Gansiniec - córka Ryszarda i Zofii, oraz dr hab. Krzysztof Królczyk ${ }^{1}$ historyk, prof. UAM w Poznaniu².

Ryszard Gansiniec (1888-1958; przed wojną używał formy nazwiska Ganszyniec) należał do najwybitniejszych i najbardziej rozpoznawanych polskich humanistów. Po uzyskaniu świadectwa dojrzałości w 1909 r., w latach 1909-1910

1 K. Królczyk, Próba utworzenia katedry historii Bizancjum na Uniwersytecie Jana Kazimierza we Lwowie. Przyczynek do dziejów bizantynistyki w Polsce, „Studia Europaea Gnesnensia” 21, 2020, s. 77-102; idem, Historia starożytna, [w:] Historia w Uniwersytecie Lwowskim. Badania i nauczanie (do 1939 r.), red. J. Maternicki et al., Rzeszów 2016, s. 177-201; idem, Ludwik Ćwikliński - profesor filologii klasycznej na Uniwersytecie Lwowskim, [w:] Przedwojenny Lwów i jego uczeni. Sylwetki działalność naukowa - osiągnięcia, red. P. Brzegowy, S. Dorocki, Kraków 2016, s. 87-114; idem, Historia starożytna na Uniwersytecie Jana Kazimierza we Lwowie w okresie międzywojennym, [w:] Історія та історики у Львівському університеті: традіиії та сучасність 1661-2015, red. Л. Зашкільняк, П. Серженга, Львів 2015, s. 122-132; idem, Kazimierz Zakrzewski (1900-1941), [w:] Złota ksiegga historiografii lwowskiej XIX i XX w., t. 2, red. J. Maternicki et al., Rzeszów 2014, s. 551-564; idem, Konstanty Chyliński (1881-1939), [w:] Złota księga..., s. 343-364.

2 Warto nadmienić, że współpraca R. Gansiniec i K. Królczyka przyniosła efekt również w postaci drugiego wydania Notatek Lwowskich 1944-1946 Ryszarda Gansińca. Zob.: R. Gansiniec, Notatki lwowskie 1944-1946, red. R. Gansiniec, K. Królczyk, wyd. 2 uzup., Warszawa 2020. 
odbył kurs teologii w Mödling pod Wiedniem, a następnie studiował 3 semestry (1911-1912) filologię klasyczną i germanistykę na uniwersytecie w Münster. W trakcie studiów zdobył pierwszą nagrodę w konkursie zorganizowanym przez

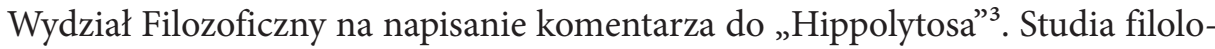
giczne w latach 1912-1915 kontynuował na Uniwersytecie Berlińskim. Egzamin obejmujący filologię klasyczną, germanistykę oraz filozofię złożył w 1915 r. i uzyskał tytuł kandydata filozofii w zakresie filologii klasycznej, germanistyki i filozofii ścisłej. W 1915 r. został wysłany na Uniwersytet Warszawski, gdzie powołano go na organizatora seminarium filologii klasycznej. W 1917 r. uzyskał doktorat $\mathrm{z}$ zakresu religioznawstwa na podstawie pracy De Agathodaemone . $^{4}$ W latach 1918-1920 pracował na Uniwersytecie w Poznaniu. Od 1920 r. do wybuchu II wojny światowej był związany ze Lwowem, gdzie pracował na Uniwersytecie Jana Kazimierza. Po tzw. „repatriacji” w 1946 r. pracował na Uniwersytecie Wrocławskim, a następnie od 1948 r. został powołany na profesora Uniwersytetu Jagiellońskiego, na którym pracował aż do śmierci. W latach 1947-1948 na zaproszenie Szwedzkiego Instytutu Wymiany Kulturalnej z Zagranicą (szw. Svenska Institutet for Kulturellt Utyte med Utlander) przebywał w Szwecji, wygłaszając szereg wykładów. Ryszard Gansiniec zmarł 8 marca 1958 r. w Krakowie.

Zofia Gansiniec z domu Przygoda (1919-1988) odbyła studia na UJK we Lwowie, dyplom magistra filozofii otrzymała po wojnie we Wrocławiu (na Uniwersytecie i Politechnice we Wrocławiu) w 1946 r. Doktorat uzyskała w 1948 r. na Uniwersytecie Warszawskim. Po śmierci Ryszarda Gansińca w 1958 r. redagowała „Filomatę" - uznawane za dzieło życia męża, pismo skierowane do młodzieży popularyzujące kulturę antyku, założone i redagowane przez Gansińca od 1929 r. we Lwowie ${ }^{5}$. Brała aktywny udział w życiu naukowym, wyjeżdżała na ekspedycje archeologiczne m.in. na Krym (1957), czynnie uczestniczyła w działalności Polskiego Towarzystwa Filologicznego oraz Polskiego Towarzystwa Archeologicznego. Zmarła 17 kwietnia 1988 r. w Krakowie.

Listy Ryszarda i Zofii Gansińców znajdują się w prywatnym archiwum Radości Gansiniec. Docelowo mają zostać zdeponowane do Zakładu

3 Nagrodzona praca R. Gansińca została wydana w 1913 r. w Lipsku pt. Hippolytos' Capitel gegen die Magier.

4 Według relacji prof. Jerzego Łanowskiego, Gansiniec napisał dwie rozprawy doktorskie. Pierwsza została odrzucona przez prof. U. Wiliamowitza ze względu na szerokie tło porównawczo-etnograficzne, drugą - „właściwą” rozprawę Gansiniec miał napisać w przeciągu dwóch tygodni, wygrywając jednocześnie zakład o kosz szampana. Zob.: J. Łanowski, Ryszard Gansiniec (1888-1958), „Kwartalnik Historii Nauki i Techniki” 1958, nr 3-4, s. 630.

5 M. Rogoż, Czasopismo popularnonaukowe „Filomata” (1929-1996), [w:] Kraków-Lwów: książki, czasopisma, biblioteki XIX i XX wieku, t. 5, red. J. Jarowiecki, Kraków 2001, s. 671-672. 
Narodowego im. Ossolińskich we Wrocławiu. Korespondencja została opublikowana po raz pierwszy. Cezura czasowa przyjęta w publikacji obejmuje lata 1946-1948, choć pierwszy list jest datowany na koniec grudnia 1945 r., ostatni nosi datę 18 października 1948 r. Praca składa się z trzynastu zasadniczych rozdziałów uszeregowanych i zatytułowanych tematycznie: I - Korespondencja dotyczaca szukania paczek z ksiażkami ze Lwowa (s. 16-24), II - Listy od znajomych ze Lwowa (s. 25-37), III - Korespondencja z Czerniawy Zdroju i Siemianowic Ślaskich (s. 38-44), IV - Korespondencja dotycząca spraw wrocławskich i $z$ okresu pobytu prof. R. Gansińca w Gdyni (s. 45-75), V - Listy różne (s. 76-85), VI - Listy z wakacji 1947 r. (s. 86-93), VII - Listy z lata i jesieni 1947 r. (s. 94-101), VIII Szwecja 1947-1948. Listy Ryszarda Gansińca i Zofii Gansiniec (s. 102-232), IX Listy od Romana Ingardena i Izy Bieżuńskiej-Małowist (s. 233-241), X - Listy różne (s. 242-249), XI - Listy od studentek i asystenta ze Lwowa (s. 250-254), XII - Listy zwiazane z obrona doktoratu Zofii Gansiniec 1948 r. (s. 255-264), XIII - Listy od Mieczysława Brożka (s. 265-269).

Poszczególne rozdziały zostały opatrzone komentarzem w postaci wspomnień Radości Gansiniec, stanowiącym swoiste dopełnienie korespondencji. Praca zakończona jest krótkimi tekstami redaktorki tomu dotyczącymi 70-lecia Nauki Polskiej we Wrocławiu oraz biogramami rodziców.

Listy Ryszarda i Zofii Gansińców oraz otrzymywana od znajomych korespondencja przysyłana na nowy, powojenny adres na podwrocławskim Oporowie to niezwykle interesujący obraz życia uczonych na tle wydarzeń - tych wielkich, będących konsekwencjami zawirowań wojennych, jak i tych w skali mikro - zwykłych codziennych obowiązków powojennej „repatriacyjnej” rzeczywistości. Wyjazd ze Lwowa do nowej „ludowej” Polski oznaczał bowiem dla wielu drogę w nieznane. Lektura korespondencji przynosi czytelnikowi unikalne informacje dotyczące powojennego życia nie tylko samych Gansińców, ale wielu im podobnych ludzi zmuszonych na zawsze opuścić swoje kresowe „małe ojczyzny”6. Obok przedstawianych spraw życia codziennego, dotykającego najbardziej podstawowych potrzeb, a wręcz egzystencji, otrzymujemy obraz i liczne informacje dotyczące okoliczności powstawania świata nauki w kolejnych ośrodkach akademickich i trudnych wyborów bohaterów-korespondentów. Listy otrzymywane od byłych studentów, bliższych i dalszych znajomych świadczą o głębokich relacjach Gansińca, wspominanego jako życzliwego nauczyciela. Na szczególną uwagę zasługują rozdziały z listami od

$6 \quad$ Zob.: J. Krasnodębski, Z Wilna nad Wilia do „Wilna nad Wista”. Ekspatriacja i osiedlenie mieszkańców Wileńszczyzny w Toruniu (1944-1948), Toruń 2019. 
wybitnych uczonych Romana Ingardena ${ }^{7}$ i Izy Bieżuńskiej-Małowist ${ }^{8}$, a także korespondencja prowadzona ze Stefanem Srebrnym z toruńskiego Uniwersytetu Mikołaja Kopernika9 . Niezwykle ważną częścią jest rozdział VIII zawierający listy pisane przez uczonego podczas jego pobytu w Szwecji. Kolejne karty przybliżają nam życie i obyczaje, zarówno te zwykłe, codzienne jak i naukowe Skandynawów, opatrzone stosownymi komentarzami filologa. Warto nadmienić, że okres pobytu w Szwecji latach 1947-1948 był do tej pory najmniej znanym i najsłabiej udokumentowanym epizodem w życiu Gansińca. Naukowa kariera Zofii Gansiniec, równolegle wychowującej dwójkę dzieci, udokumentowana w XII rozdziale, to zmuszający do refleksji obraz trudów łączenia obowiązków matki i naukowca. Zasługą redaktorów naukowych Nowego adresu... są liczne przypisy przedstawiające przywoływane w tekście postaci oraz objaśniające wydarzenia. Uzupełnienie całości stanowi strona ikonograficzna, na którą składa się 18 dokumentów i fotografii, w tym m.in.: legitymacje uniwersyteckie prof. Ryszarda Gansińca i mgr Zofii Gansiniec, a także dyplom doktorski tej ostatniej.

Warto sięgnąć po Nowy adres..., publikacja stanowi bowiem uzupełnienie naszej dotychczasowej wiedzy na temat życia profesora Gansińca ${ }^{10}$ i jego rodziny, ale także jest unikalnym, choć subiektywnym obrazem losów lwowskiej inteligencji - „repatriantów” w nowej ludowej Polsce. Troski życia codziennego

7 Roman Ingarden (1893-1970) - filozof, autor licznych dzieł z zakresu epistemologii, ontologii i estetyki, autor przekładu Krytyki czystego rozumu I. Kanta. Profesor Uniwersytetu Jana Kazimierza (1925-1944), po II wojnie światowej profesor Uniwersytetu Mikołaja Kopernika (1945-1946) i Uniwersytetu Jagiellońskiego (1946-1950, 1956-1963), członek Polskiej Akademii Umiejętności i Polskiej Akademii Nauk.

8 Iza Bieżuńska-Małowist (1917-1995) - historyk starożytności, profesor Uniwersytetu Warszawskiego, wieloletnia współredaktor „Przeglądu Historycznego”, specjalista w zakresie dziejów społecznych i gospodarczych świata hellenistycznego i rzymskiego. Szczególnie interesowały ją zagadnienia niewolnictwa i życia kobiet w antyku.

9 Stefan Srebrny (1890-1962) - filolog klasyczny, tłumacz, znawca dramatu antycznego. Tłumacz dzieł Ajschylosa, Arystofanesa i Eurypidesa. Wykładowca Uniwersytetu Lubelskiego (1918-1923) oraz Uniwersytetu Stefana Batorego (1923-1939). Po II wojnie światowej profesor Uniwersytetu Mikołaja Kopernika (1945-1960), dyrektor artystyczny Teatru w Toruniu.

10 Do tej pory brakuje pełnego monograficznego opracowania życia i działalności naukowej Ryszarda Gansińca. Zob.: I. Bieżuńska-Małowist, Ryszard Gansiniec (1888-1958), „Meander” 9, 1958, s. 301306; M. Chrostek, Złote lata polonistyki lwowskiej (1919-1939), Rzeszów 2016, s. 304-321; Z. Gansiniec, Ryszard Gansiniec (1888-1958), „Filomata” 387, 1988, s. 302-314; K. Kumaniecki, Działalność naukowa Ryszarda Gansińca, „Przegląd Humanistyczny” 3(6), 1958, s. 90-96; J. Łanowski, op. cit., s. 630; Prof. dr Ryszard Gansiniec: $z$ życia i twórczości. Materiały posesyjne, red. J. Śliwiok, Katowice 1997; S. Strabryła, Profesor Ryszard Gansiniec (sylwetka uczonego i człowieka), „Filomata” 390, 1989, s. 97-108; T. Ulewicz, Ryszard Gansiniec i jego badania nad kultura umysłowa polskiego średniowiecza i renesansu, [w:] Portrety uczonych polskich. 51 sylwetek humanistów, wyb. A. Biernacki, Kraków 1974, s. 72-197. 
relacjonowane równolegle $\mathrm{z}$ „wielkimi” tematami - dotyczącymi spraw naukowych, zebrane w listach wysyłanych pod tytułowy, nowy wrocławski adres na Oporowie, uzupełniają naszą wiedzę o powojennych losach przybyłej z Kresów Wschodnich inteligencji. Listy rodziny Gansińców stanowią nieocenione źródło wiedzy na temat życia prywatnego Ryszarda i Zofii Gansińców. Ta bogata i niezwykle interesująca epistolografia powinna stać się inspiracją dla badaczy życia powojennej inteligencji polskiej do napisania biografii wybitnego filologa klasycznego, nauczyciela i wychowawcy.

Rafał Michliński - pracownik Instytutu Pamięci Narodowej, do jego głównych zainteresowań badawczych należą historia Flotylli Pińskiej oraz dzieje Kresów Wschodnich II RP.

e-mail: rafal.michlinski@gmail.com 